\title{
Using social media to enhance the peer mentoring experience at the University of Southampton
}

\author{
Dr Eleanor Quince \\ University of Southampton, UK
}

Charlotte Medland

University of Southampton, UK

\begin{abstract}
This case study explains how social media was used in the pilot year of a student-led peer mentoring initiative. The University of Southampton, faculty of Humanities, peer mentoring scheme was launched in September 2014 with a cohort of 750 undergraduate students across seven subject areas. The scheme is part of the wider, student-led, careers activity across all year groups within the faculty, otherwise known as the 'mission employable' project. Social media, including Facebook and Twitter, was used to engage mentors and mentees and to communicate with students throughout the scheme. Facebook groups were introduced to help maintain contact, initially between the student peer mentoring coordinator and the student mentors, then between the mentors and their mentees. The familiarity of Facebook was a deciding factor in the selection of appropriate media for use within the scheme. At the mid- and end- point evaluation reviews, mentors praised the inclusion of social media platforms and asked that greater use be made of them in future. The case study concludes that social media led to an increase in student engagement and an enhanced student experience within the faculty.
\end{abstract}

Keywords: peer mentoring; employability; social media; student partnership. 


\section{Introduction}

Peer mentoring schemes aim to facilitate the swift integration of first year students into university life (Hill and Reddy, 2007). In recent years UK higher education institutions (HEls) have been keen to establish schemes as a means of providing a friendly supportive environment for new starters while giving current students an opportunity to develop skills (Collings et al., 2015). The University of Liverpool (Lunt, 2014), for example, defines their peer mentoring scheme as aiming to:

Build up the confidence of the mentee and encourage independence. It is very much a two-way process and the benefits for ... [the] mentor include developing transferable skills, such as communication and empathy. [The Mentor] role is not to counsel a mentee, nor is it to coach them. The role is to [act as a facilitator of knowledge about the course and the university, perhaps even] the city [...] and local resources (doctors, shops, clubs...etc.). (Lunt, 2014, p.3).

This aim of 'facilitation' is supported by research which indicates that the first 6-8 weeks of a new students' time at university are the most crucial (Wilcox et al., 2005, p.715). During this period the new student is at a much higher risk of dropping out of university, due to the shock of a new cultural, social and academic environment, and/or as a result of the higher education workload (Smith and Naylor, 2001, p.391). Fear of the unknown, concern that they won't make friends, not knowing their way around - are all things which can be eased through the mechanism of peer support. Literature focussing specifically on peer mentoring is scarce (Andrews and Clarke, 2011, p.16). Work undertaken through the Higher Education Academy (HEA) by a group of 22 UK HEls to examine 'what works' for student retention explored a range of material on peer support from a variety of fields, identifying peer mentoring within higher education as:

The creation of a true 'win-win-win' situation in which new students belong, existing students develop new skills and institutions experience minimal student attrition. Peer mentoring offers an approach whereby students help students discover the new world of university life through the formation of safe and supportive peer relationships. (Andrew and Clarke, 2011, p.5). 
The research undertaken through the HEA 'what works' project highlighted that the creation of these schemes needs to be considered from the student perspective (Andrews and Clarke, 2011, p.12), holding a relevancy for both mentees and those students acting as mentors. The use of an established and relevant means of communication aligned with the pre-university environment, such as Facebook or Twitter, can act as a bridge between home and higher education (Haeger et al., 2014, p.3).

During 2013/14 my own HEl embarked on a review of its 'peer support' offer with the intention of ascertaining what schemes were running, where they were rooted - at departmental, school or faculty level - and if there were any gaps. The faculty of Humanities was identified as having little to no peer-support provision across its seven subject areas (Archaeology, English, Film, History, Modern Languages, Music and Philosophy). As the faculty's Director of Employability, I was tasked with deciding what kind of peer-support scheme would work for Humanities and how we might implement it. This case study details the establishment of our faculty-wide, student-led peer mentoring scheme, piloted during the academic year 2014/15, and, in particular, how we made use of social media to ensure the scheme's success.

\section{Methodology}

In July 2014 a student 'peer mentoring coordinator' was hired on a three-month internship. The intern's role was to research existing peer mentoring schemes in HEls across the UK ${ }^{1}$ and to work with the faculty Director of Employability to establish a suitable scheme for Humanities. The identified six key indicators of success within existing schemes:

- Engagement within the first 6-8 weeks of a new students' time at university.

- Clear expectations established for, and agreed with, mentors at the outset of the scheme.

- Provision of training for mentors which is clearly aligned to the expectations of the scheme.

\footnotetext{
1 The coordinator considered schemes already established at Southampton University, in the Management and Engineering Schools, alongside schemes run at the Universities of Aston, Edinburgh, Exeter, Leeds, Liverpool, Manchester, Newcastle, Sussex and York St. John.
} 
- Management of mentees' expectations from the outset including a definition of what a mentor is and is not.

- A clear structure to frame activity, but with flexibility in order to promote relaxed and friendly relationships.

- Continuous support provision for mentors and mentees.

The coordinator highlighted the use of social media within a peer mentoring scheme at the University of Newcastle. Newcastle had established a WordPress blog site (https://newcastlementors.wordpress.com/) which was maintained as a support structure for mentors and coordinators, ensuring that essential information was shared and enabling student access across all devices. The view of the coordinator was that this site went partway to establishing the key success indicators identified through her research. However, the site was designed to connect only with mentors, not with mentees, thus creating a barrier between these two groups.

Based on her findings, the coordinator proposed a scheme: led by a student coordinator; running during semester one only and kick-started at induction, the week new students arrive; mentor and mentee handbooks outlining responsibilities which both groups needed to agree to; training for all mentors prior to the start of the semester; informal group meetings to support new students in a relaxed and friendly atmosphere; the involvement of Humanities subject societies to support mentor recruitment and encourage mentee integration; use of social media to facilitate such integration, and encourage mentee interaction with other university activities; rewards for mentors; readily available key support contacts at both faculty and university levels; and close collaboration with personal academic tutors.

The coordinator presented her findings and proposal to her peers and university staff, showcasing the Newcastle WordPress site as a means of utilising social media within a peer mentoring scheme. She collected student views via email and social media on different social media platforms and their suitability for use within peer mentoring (Table 1). 
Table 1. Outcomes of research into social media for peer mentoring in higher

\section{education.}

\begin{tabular}{|c|c|c|c|}
\hline $\begin{array}{l}\text { Social } \\
\text { media } \\
\text { platform }\end{array}$ & $\begin{array}{l}\text { Positives of use within HE } \\
\text { peer mentoring }\end{array}$ & $\begin{array}{l}\text { Negatives of use } \\
\text { within HE peer } \\
\text { mentoring }\end{array}$ & Outcome \\
\hline Facebook & $\begin{array}{l}\text { - Most widely-used social } \\
\text { media platform amongst } \\
\text { our student cohort. } \\
\text { - Students already spend } \\
\text { time on Facebook for social } \\
\text { reasons so easy to expand } \\
\text { this use to mentoring. } \\
\text { - Student societies use } \\
\text { Facebook for publicity, } \\
\text { recruitment and information } \\
\text { - we could harness this. } \\
\text { - Some mentors were } \\
\text { already contacting the peer } \\
\text { mentoring coordinator } \\
\text { unofficially using Facebook } \\
\text { if they were off campus or } \\
\text { abroad. }\end{array}$ & $\begin{array}{l}\text { - Some students do } \\
\text { not like to mix their } \\
\text { social and } \\
\text { academic media. } \\
\text { - Not all students } \\
\text { have Facebook. } \\
\text { - Mentoring } \\
\text { colleagues/mentees } \\
\text { would be able to } \\
\text { see private } \\
\text { information. } \\
\text { - Quite difficult to } \\
\text { walk away from - } \\
\text { mentees would be } \\
\text { able to access } \\
\text { mentors at all times, } \\
\text { using mobile apps, } \\
\text { and would be able } \\
\text { to see if a mentor } \\
\text { had read a } \\
\text { message. }\end{array}$ & $\begin{array}{l}\text { First choice of social } \\
\text { media platform for } \\
\text { current students, due } \\
\text { to the amount of } \\
\text { university presence } \\
\text { already there. } \\
\text { However, for the } \\
\text { purposes of peer } \\
\text { mentoring, students } \\
\text { must be trained in } \\
\text { online etiquette and } \\
\text { ensure that mentors } \\
\text { and mentees are in } \\
\text { control of what they } \\
\text { share online. }\end{array}$ \\
\hline Instagram & $\begin{array}{l}\text { - Fast-growing platform } \\
\text { among undergraduate } \\
\text { students. } \\
\text { - Many students already } \\
\text { have an account. } \\
\text { - Allows presentation in a } \\
\text { highly visual way - useful } \\
\text { for recruitment and } \\
\text { publicity. } \\
\text { - Allows you to share posts to } \\
\text { other platforms like Twitter } \\
\text { and Facebook. }\end{array}$ & $\begin{array}{l}\text { - Current coordinator } \\
\text { does not use the } \\
\text { platform. } \\
\text { - Students do not tend } \\
\text { to use it for browsing } \\
\text { or chatting, but to } \\
\text { upload photos. } \\
\text { - Difficult to use for } \\
\text { information without } \\
\text { 'spamming' other } \\
\text { users. }\end{array}$ & $\begin{array}{l}\text { An excellent way of } \\
\text { reaching current } \\
\text { students, but not as } \\
\text { many privacy settings } \\
\text { as some of the other } \\
\text { platforms. }\end{array}$ \\
\hline Pinterest & $\begin{array}{l}\text { - Up and coming platform. } \\
\text { - Allows a mix of information } \\
\text { and images. } \\
\text { - Creative and youthful } \\
\text { format. } \\
\text { - Already have an account for } \\
\text { our central careers service, } \\
\text { so it is being adopted more } \\
\text { widely within higher } \\
\text { education. }\end{array}$ & $\begin{array}{l}\text { - Current coordinator } \\
\text { does not use the } \\
\text { platform, which } \\
\text { means they would } \\
\text { have to spend } \\
\text { valuable time } \\
\text { learning. } \\
\text { - Not as popular as } \\
\text { some other } \\
\text { platforms. } \\
\text { - Not as useful for } \\
\text { information as it is } \\
\text { for media clippings. }\end{array}$ & $\begin{array}{l}\text { It would take too long } \\
\text { to learn this platform } \\
\text { considering the } \\
\text { current number of } \\
\text { university students } \\
\text { who use it regularly. } \\
\text { However, we will } \\
\text { ensure we stay up to } \\
\text { date with } \\
\text { developments in case } \\
\text { Pinterest could be } \\
\text { useful in the future. }\end{array}$ \\
\hline Twitter & $\begin{array}{l}\text { - Many faculty members and } \\
\text { departments already have } \\
\text { Twitter accounts: easy to } \\
\text { share information and raise } \\
\text { awareness. } \\
\text { - Useful for keeping updated } \\
\text { with best practice in other } \\
\text { HEls through hashtags, }\end{array}$ & $\begin{array}{l}\text { - Not currently the } \\
\text { most widely-used } \\
\text { platform for students. } \\
\text { - Cannot give out } \\
\text { detailed information } \\
\text { due to the } 140 \\
\text { character limit on } \\
\text { tweets. }\end{array}$ & $\begin{array}{l}\text { Agree that this is a } \\
\text { useful platform, but } \\
\text { that it would be best } \\
\text { utilised as a } \\
\text { complement to } \\
\text { Facebook, to ensure } \\
\text { that we are reaching }\end{array}$ \\
\hline
\end{tabular}




\begin{tabular}{|c|c|c|c|}
\hline & $\begin{array}{l}\text { accounts and academic } \\
\text { lists. } \\
\text { - Easy to see a reaction to } \\
\text { the scheme in real time } \\
\text { using hashtags. } \\
\text { - An increasing number of } \\
\text { undergraduate students are } \\
\text { using Twitter. } \\
\text { - We teach students about } \\
\text { the power of Twitter for } \\
\text { professional development in } \\
\text { our employability module: } \\
\text { this could encourage further } \\
\text { engagement. }\end{array}$ & $\begin{array}{l}\text { - Quite difficult to walk } \\
\text { away from - } \\
\text { mentees would be } \\
\text { able to access } \\
\text { mentors at all times } \\
\text { using mobile apps. } \\
\text { - Cannot control who } \\
\text { sees your tweets, } \\
\text { unless you have a } \\
\text { completely private } \\
\text { account. }\end{array}$ & $\begin{array}{l}\text { both staff and } \\
\text { students. }\end{array}$ \\
\hline WordPress & $\begin{array}{l}\text { - Precedent at another HEI } \\
\text { (Newcastle). } \\
\text { - University already has a } \\
\text { license. } \\
\text { - Student training available. } \\
\text { - 'One-stop' information } \\
\text { point. }\end{array}$ & $\begin{array}{l}\text { - Current coordinator } \\
\text { does not use the } \\
\text { platform. } \\
\text { - Not currently the } \\
\text { most widely-used } \\
\text { platform for students. } \\
\text { - Open forum, so the } \\
\text { public could access } \\
\text { all information. }\end{array}$ & $\begin{array}{l}\text { It would take too long } \\
\text { to learn this platform } \\
\text { considering the } \\
\text { current number of } \\
\text { university students } \\
\text { who use it regularly. } \\
\text { However, we will } \\
\text { ensure we stay up to } \\
\text { date with } \\
\text { developments in case } \\
\text { blogging could be } \\
\text { useful in the future. }\end{array}$ \\
\hline
\end{tabular}

Facebook was identified as the form of social media most in use. Students noted that Facebook groups were often established around modules and student societies, successfully facilitating communication and effective group working. Students admitted to spending a considerable amount of time on Facebook, staying in touch with family and friends, so keeping up with activity within the groups was easy. It was reported that, in contrast to the technologies available to new students through their university course, Facebook was familiar. The group and network structure would encourage the 'sense of belonging' in mentees identified in the HEA project (Andrews and Clarke, 2011, p.5) as being central to feeling part of the university (Cashmore et al., 2012). The additional online interaction Facebook promotes would also encourage mentors to demonstrate their digital literacy skills while simultaneously creating new personal partnerships. Based on this positive feedback, the coordinator presented a case for utilising Facebook pages and groups to establish the peer mentoring scheme and support mentors and mentees. The use of Facebook would be supported by other social media platforms, as a means of raising awareness of the scheme and ensuring maximum reach during the recruitment phase. 


\section{Process}

The coordinator's proposals were agreed and the identification of mentors began in midJuly. An online application form was created for mentors using the university's i-survey (a secure questionnaire portal). This was publicised by via email, Facebook, Twitter and WordPress so that as many students as possible could be reached during the summer vacation period. The application portal remained open for one month. On closure, the coordinator chose the successful mentor candidates based on their motivation and enthusiasm for the role, then notified new mentors and matched them into pairs. The matching process ensured that mentor pairs were from the same discipline, but wherever possible - at different levels of study, so that incoming students would get insight into as much of the university experience as possible. Once the incoming student numbers had been confirmed in early September, mentor pairs were allocated a group of up to 15 mentees. Mentors sent their mentees an electronic 'welcome letter' and a photograph of themselves, so that mentees could easily identify them during induction week. The mentors received their handbooks on the training day in late September.

Facebook, as our primary social media platform, was incorporated at all levels of the scheme. Initially Humanities' subject 'student society' and 'mission employable' Facebook pages were utilised to recruit mentor applicants and to relay queries to the coordinator through Facebook messenger. These same Facebook pages were used to reach out to incoming students in the run up to the start of the academic year and during induction week. A private Facebook group for mentors was set up by the coordinator. This group was used to share concerns, ask for advice and showcase bespoke resources. Through this mechanism mentors were placed at the centre of the developing pilot, enabling them to interact with one another and the coordinator to raise issues and share best practice. At key points throughout the pilot year - during recruitment, at launch and at the mid-and end-point reviews - peer mentoring was also publicised through the official 'mission employable' blog, hosted by the university's WordPress server. WordPress was used to explain the rationale behind the scheme in an accessible way, as well as showcasing mentor and mentee case studies and encouraging wider engagement on a local and national scale. 
Social media training on appropriate online etiquette was incorporated into the mentor training day in order to highlight the importance of maintaining safety and privacy during online interactions between students. The training:

- Raised awareness that, should mentors wish to connect with their mentees over social media, their mentees would have access to their personal information.

- Asked mentors not to share mobile phone numbers with mentees, particularly in an online forum.

- Stated that social media contact should be followed up with an email, so that students who are not contactable in other ways do not miss out on essential information.

- Made it clear that social media should be used to enhance the peer mentoring process, but not to replace face-to-face contact.

- Asked that, when using Facebook to contact the coordinator, mentors act with due consideration.

At the training day mentors were encouraged to set up specific Facebook groups for their mentees and, at least initially, not to connect with them through their personal accounts. During induction week, mentors held face-to-face meetings with their mentees for the first time, continuing with fortnightly meetings throughout the semester. The Facebook groups were used to support these meetings on both a logistical and personal level: students could send apologies; ask for advice and share guidance; as well as get to know each other outside of the more formal meetings.

\section{Potential ethical issues associated with humanities peer mentoring}

We identified four main ethical challenges present within the scheme. These were:

1. Mentor and mentee confidentiality, both within the scheme and at faculty/university level.

2. Ensuring that student feedback on the scheme remains anonymous.

3. Using students' images in promotional/published materials, both in print and online.

4. Ensuring that students were 'culture-friendly' at all times. 
We addressed these challenges by:

1. Adding confidentiality agreements to the mentor and mentee handbooks, and explaining their importance at the training day.

2. At both the mid- and end-point reviews, mentors and mentees were told in advance that their comments, ideas and feedback might be used at both faculty and university levels, but that this information would always be anonymised, only ever being identified by subject if required. No names were used in email correspondence or reports shared by the coordinator with other members of staff.

3. At all mentor meetings, trainings and reviews, students were advised when photos might be taken and could opt out of their image being used if they wished. No one did, believing that the use of 'real' promotional material would encourage further engagement with the scheme in the future.

4. Mentors were trained on the differences in culture that may arise among mentees (e.g. students who do not consume alcohol) and further guidance was provided in the mentor handbook.

To ensure student privacy, at the start of the scheme it was important to make clear to both mentors and mentees when information should be shared and should remain confidential. Prospective mentors had to agree to the following statement before beginning their role: In accordance with the Data Protection Act 1998 the information provided on this form will be used to assess my suitability for the post and, if accepted, this information will form the basis of my volunteer personnel file. I understand that the information provided on this form may be entered onto a computerised database. I agree that if I am matched with other students, the information given on this form may be shared with them.

Handbooks for mentors and mentees clearly outlined respective rights and responsibilities. These ensured that the mentor-mentee relationship was clearly defined and respected from the start of the scheme (Table 2). 
Table 2. Responsibilities of the mentor and mentee.

\begin{tabular}{|c|c|}
\hline \multicolumn{2}{|l|}{ Mentors } \\
\hline - Discussing and agreeing boundaries & $\begin{array}{l}\text { - Listening }-100 \% \text { attention should be } \\
\text { given to mentees }\end{array}$ \\
\hline - Attendance & - Being honest \\
\hline - Wanting to be there & - Being realistic \\
\hline - Giving constructive feedback & - Supporting the mentee \\
\hline - Enabling the mentee to achieve their aims & $\begin{array}{l}\text { - Respecting the confidentiality of the } \\
\text { mentee }\end{array}$ \\
\hline $\begin{array}{l}\text { - Being respectful to others views and } \\
\text { beliefs }\end{array}$ & $\begin{array}{l}\text { - Following any policies/procedures within } \\
\text { the scheme }\end{array}$ \\
\hline - Behaving responsibly & - Knowing when to ask for help \\
\hline \multicolumn{2}{|l|}{ Mentees } \\
\hline - Discussing and agreeing boundaries & - Attendance \\
\hline - Respecting the mentor & - Listening \\
\hline - Wanting to be there & - Being honest \\
\hline - Making the most of the opportunity & $\begin{array}{l}\text { - Following through on any action points } \\
\text { agreed }\end{array}$ \\
\hline - Taking part in the feedback process & - Taking part in the evaluation process \\
\hline
\end{tabular}

(Source: University of Southampton, 2014, pp. 6-7).

\section{Review and outcomes}

As part of the pilot year process for 2014/15 we held mid- and end-point reviews with all mentors in weeks 7 and 12 of semester one. This enabled mentors to raise any concerns they had, or challenges they were facing, in a supportive and confidential setting. The results of these reviews have helped us to identify the extent to which social media support had worked, and what we wished to change for future iterations of the scheme. Digital literacy can be a challenge for students entering higher education, as they are introduced to new software and media platforms without the detailed training they might have been used to at school. We discovered at our mid-point review that new students were nervous about approaching staff for help on this issue, but happy to discuss it with their mentors. Digital literacy queries were often raised through the Facebook support 
groups that had been set up for mentees. Mentors used this platform alongside face-toface meetings to successfully train their mentees in using the university's digital services, taking the time to show them step-by-step demonstrations and sharing 'how to' documents and web links. The feedback from mentees who experienced such training was universally positive. As a result, we have made the recommendation that dedicated academic digital platform sessions are run by $2015 / 16$ mentors during the first month of the scheme. Mentees reported that they struggled to remember the information on 'support services' and resources given to them during induction. To help resolve this issue, an e-copy of the mentee handbook was posted to the 'mission employable' Facebook page for ease of access. As mentees responded well to this, for 2015/16 we will be introducing a dedicated Humanities peer mentoring website which will act as a 'one-stop shop' for first-year students settling into university life. The site will bring together existing resources, actively signposting rather than repeating information hosted elsewhere.

Mentors raised positive outcomes from using social media at both reviews. Many new students were not used to using email for academic or professional purposes and did not check it regularly enough in the first few weeks. Mentors reported that it was quicker and easier to contact mentees using social media during this period. Facebook quickly became the favoured means of communication for urgent contact as more mentors had easy access to this platform on their phone and could see whether the coordinator was online, making it easy to message queries during a meeting. Some of the mentor-mentee groups continued after the scheme had officially ended, maintained by mentors who said they were happy to stay in touch with their mentees on a less formal basis.

Although the primary platform used was Facebook, the use of Twitter increased over the course of the year. As a result, a dedicated Humanities peer mentoring Twitter account for 2015/16 and a \#HumsTopTips will be introduced to encourage incoming students to engage with mentors through this medium before they arrive. At the end-point review meeting in January 2015, mentors praised the availability of the coordinator through social media, and highlighted it as an essential factor in the continuance of the scheme for 2015/16. 


\section{Conclusions}

The use of social media within Humanities peer mentoring was a key factor in the success of the scheme. Well received by mentors and mentees alike, the use of Facebook meant that all the students involved knew they could access help whenever they needed it. Any concerns that the coordinator may be bombarded with questions were unfounded: all students used social media in a respectful and supportive manner.

Harnessing familiar social media networks to link new and current students gives both parties the confidence to interact with their peers, and gave mentees an additional support option outside of their face-to-face meetings. Mentors also gained a sense of ownership over the scheme by creating their own subject-level online communities for their mentees, and by sharing advice and resources with other mentors through the private peer mentors Facebook group. Students who participated in the scheme viewed social media as a clear indicator of the student-led nature of the project. For the future we aim to increase our engagement with social media, working with our student partners to introduce:

- A YouTube channel to distribute advice and guidance in a more visually-dynamic and approachable format.

- Storify to document events and activities.

- Linkedln as a means of staying in touch with past mentors and connect them with current students.

- A social media links page on the Humanities peer mentoring website. The page would include links related to the mentoring scheme; support services; university resources; subject societies; local information and a list of student discounts available.

\section{References}

Andrews, J. and Clark, R. (2011) Peer mentoring works! How peer mentoring enhances student success in higher education. Available at: http://eprints.aston.ac.uk/17968/1/Peer mentoring works.pdf (Accessed: 3 May 2016). 
Cashmore, A., Cane, C. and Scott, J. (2012) "Belonging" and "intimacy" factors in the retention of students - an investigation into the student perceptions of effective practice and how that practice can be replicated, University of Leicester. Available at: https://www.heacademy.ac.uk/resources/detail/what-works-studentretention/Leicester What Works Final Report (Accessed: 11 August 2014).

Collings, R., Swanson, V. and Watkins, R. (2015) 'Peer mentoring during the transition to university: assessing the usage of a formal scheme within the UK', Studies in Higher Education, March. http://dx.doi.org/10.1080/03075079.2015.1007939

Haeger, H., Wang, R. and BrckaLorenz, A. (2014) 'Bridge or barrier: the impact of social media on engagement for first-generation college students', The Power of Education Research for Innovation in Practice and Policy: American Educational Research Association Annual Meeting. Pennsylvania Convention Center, Philadelphia, Pennsylvania, USA 3-7 April 2014. Available at: http://www.aera.net/Publications/OnlinePaperRepository/AERAOnlinePaperReposit ory/tabid/12720/Owner/743469/Default.aspx (Accessed: 20 April 2016).

Hill, R. and Reddy, P. (2007) 'Undergraduate peer mentoring: an investigation into processes, activities and outcomes', Psychology Learning and Teaching, 6(2), pp. 98-103. http://dx.doi.org/10.2304/plat.2007.6.2.98

Lunt, P. (2015) Handbook for peer mentors (2015-16). Available at: http://www.liv.ac.uk/eddev/supporting-students/peer-mentoring/ (Accessed: 3 May 2016).

Medland, C., Tribe, J., Dudley, A., Smith, V. and Quince, E. (2015) 'Mission employable: creating a student-led employability strategy for the faculty of humanities, University of Southampton', The Journal of Educational Innovation, Partnership and Change, 1(1) [Online]. Available at:

https://journals.gre.ac.uk/index.php/studentchangeagents/article/view/207 (Accessed: 17 March 2015).

Quince, E. M. (2015) TEL conference 2015 eleanor quince [video file]. Harnessing technology for employability: digital literacy skills development in student-led career 
activity, Technology Enhanced Learning (TEL) Conference 2015, University of Southampton. YouTube video, 23:31, posted by ILlaD UoS, 15 May 2015. Content: Retrieved from: https://www.youtube.com/watch?v=ZsjFhVMHQwY

Smith, J.P. and Naylor, R.A. (2001) 'Dropping out of university: a statistical analysis of the probability of withdrawal for UK university students', Journal of the Royal Statistical Society: Series A (Statistics in Society), 164(2), pp. 389-405. http://dx.doi.org/10.1111/1467-985X.00209

University of Southampton (2014) Mentor handbook: University of Southampton humanities undergraduate peer mentoring handbook. Available at: http://www.southampton.ac.uk/assets/imported/transforms/contentblock/UsefulDownloads Download/552200C4484C441B8C12AC0A957218BA/Ment or\%20Handbook\%20v2.pdf (Accessed: 12 February 2015).

Wilcox, P., Winn, S. and Fyvie-Gauld, M. (2005) "It was nothing to do with the university, it was just the people': the role of social support in the first-year experience of higher education', Studies in Higher Education, 30(6), pp. 707-722. http://dx.doi.org/10.1080/03075070500340036

\section{Author details}

Dr Eleanor Quince, Director of Employability, Faculty of Humanities, University of Southampton.

Charlotte Medland, Employability Coordinator, Faculty of Humanities, University of Southampton. 